\title{
COMMENTS
}

\section{Standard-Setting Organizations: Patents, Price Fixing, and Per Se Legality}

\author{
Patrick D. Curran $\dagger$
}

Standard-setting organizations (SSOs), private groups that collaboratively select and adopt uniform technical standards for goods and services, are a critical element of the modern economy. Competitors within an industry often seek to make competing products interoperable by establishing industry-wide technical standards. To accomplish this end, competing companies join SSOs and work together to select particular technologies as industry standards. This process of product standardization benefits both producers and consumers: It promotes price competition among firms, creates demand-side economies of scale, and encourages product innovation by reducing the risks of future research and development efforts. Accordingly, antitrust enforcement agencies have recognized "the important role of standard-setting in the technological innovation that will drive much of this nation's competitive vigor in the 21st Century."

However, attempts by SSOs to avoid antitrust liability for price fixing now endanger the viability of the standard-setting process. When SSOs select patented technologies as industry standards, SSO patent policies typically require patent owners to offer "fair," "reasonable," "nondiscriminatory" licenses to SSO members. These licensing obligations are left intentionally vague to avert price-fixing liability. While this equivocal language has successfully insulated SSOs from antitrust liability, patent owners and SSO members repeatedly have been forced into high-risk litigation over the definition of "fair," "reasonable," "nondiscriminatory" license terms. This litigation has exposed both SSO members and patent owners to potential liability for patent infringement and antitrust violations, and has consequently created strong disincentives to take part in the SSO process. In turn, these disincentives now threaten the important social and economic benefits of standardization.

\footnotetext{
A.B. 2001, Harvard University; J.D. Candidate 2004, The University of Chicago.

In the Matter of Dell Computer Corp, 121 FTC 616, 626 (1996).

For a discussion of SSO patent policies, see note 32 and accompanying text.
} 
In this Comment, I argue that the goals of antitrust enforcement would be best served by allowing SSOs to operate without fear of antitrust liability when fixing the price terms of licenses for single-source patents. $^{3}$ A rule of per se legality for single-source patent price bargaining would permit SSOs to bargain with patent owners over the price of patent licenses before adopting patented technologies as industry standards. This bargaining system would obviate the need for vague "fair," "reasonable," "nondiscriminatory" language in SSO policies, thereby eliminating high-risk litigation over the specific meaning of those terms and preserving incentives to participate in SSOs.

In Part I of this Comment, I describe SSOs in detail, including their welfare-enhancing functions, their relationship to patented technologies, and their connection to recent high-risk disputes over "fair," "reasonable," "nondiscriminatory" license terms. In Part II, I examine antitrust precedent in general, and price-fixing precedent in particular, and evaluate current rules in light of the broad goals of modern antitrust policy. I then argue that existing antitrust precedent poses a threat to SSOs, thus warranting a shift in antitrust enforcement policy in the context of standard setting. Finally, in Part III I propose a rule of per se legality for single-source patent price bargaining. By allowing SSO members to bargain collectively with patent owners over the price of licenses, a new rule of per se legality for single-source patent price bargaining would not only strengthen incentives to participate vigorously in SSOs, but would also reduce the price of patent licenses, increase access to industry standards, strengthen the beneficial effects of standardization, and achieve the goals of antitrust enforcement through market mechanisms.

\section{STANDARD-SETTING ORGANIZATIONS: STRUCTURE, PURPOSE, AND PROCESS}

SSOs are private groups of market participants, usually composed of multiple competitors (both incumbents and entrants) oriented horizontally and vertically within a single market (or several related markets within a single industry). These competitors voluntarily collaborate in order to establish uniform technical specifications for par-

3 The phrase "single source" is used herein as a limiting principle, allowing price bargaining to occur only between SSOs and a single patent owner. Accordingly, the single-source rule would exclude pooled, jointly owned, or cross-licensed proprietary technologies from the proposed system of bargaining and price fixing (although the rule would not exclude bargaining over multiple patents originating from a single source). This limitation is necessary to prevent SSO capture by multiple market participants; without a single-source rule, the proposed system of patent price bargaining could quickly turn SSOs into vehicles for anticompetitive harm. For a detailed discussion of single-source patent bargaining and its limitations, see Part III.B. 
ticular products and services. ${ }^{4}$ The SSOs intend the technical standards thus created to ensure interoperability among competing products, certify the quality of specific products, and provide a technical baseline for future research and product development. Generally, uniform technical standards benefit consumers by encouraging price competition between producers of interoperable products ${ }^{6}$ and benefit competitors by reducing the cost and risk of future research and development projects.'

Technical standards, and the SSOs that develop them, are a common and essential element of the modern economy. ${ }^{8}$ As early as 1987 , more than four hundred standard-setting groups had developed approximately thirty thousand voluntary standards.' Because standard setting requires particular expertise in specialized product areas, new SSOs are constantly forming to meet the needs of niche markets.

\section{A. Benefits of Standard Setting}

The specific economic benefits of standards can be divided into three categories: greater product interoperability, beneficial network

4 See Melonie L. McKenzie, Note, How Should Competing Software Programs Marry? The Antitrust Ramifications of Private Standard-Setting Consortia in the Software Industry, 52 Syracuse L Rev 139, 144-45 (2002) (noting that the typical SSO consists of "a compilation of companies already established in the marketplace and of companies just entering the marketplace").

5 See Sean P. Gates, Standards, Innovation, and Antitrust: Integrating Innovation Concerns into the Analysis of Collaborative Standard Setting, 47 Emory L J 583, 597 (1998) ("[S]tandards can quickly convey information, assure quality, increase efficiency, and ensure compatibility."); id at 601-12 (discussing how standards shift innovative activity away from radical product changes and towards process improvements and the development of complementary products).

6 See Michael G. Cowie and Joseph P. Lavelle, Patents Covering Industry Standards: The Risks to Enforceability Due to Conduct before Standard-Setting Organizations, 30 AIPLA Q J 95, 99 (2002) (noting that interoperability standards "increase[] consumer welfare by enhancing consumer choice and reducing the costs of goods").

7 See In the Matter of Dell Computer Corp, 121 FTC 616,626 (1996) (noting the important rule played by standard setting in encouraging technical innovation); Robert Pitofsky, Antitrust and Intellectual Property: Unresolved Issues at the Heart of the New Economy, 16 Berkeley Tech L J 535, 551 (2001) (describing "the private standard-setting process" as "an essential device to help introduce new products").

8 See Mark A. Lemley, Antitrust and the Internet Standardization Problem, 28 Conn L Rev 1041,1081 (1996) ("[I]n certain industries the need for standardization is so great that it is impossible to compete effectively without group standardization efforts.").

9 See Maureen A. Breitenberg, National Institute of Standards and Technology, The ABCs of Standards-Related Activities in the United States (May 1987), online at http://ts.nist.gov/ts/ htdocs/210/ncsci/stdpmr.htm (visited May 8, 2003).

10 See Jennifer L. Gray, Internet Standard Setting Bodies: Antitrust Guidelines, in 21st Annual Institute on Computer Law 525, 527 (Practising Law Institute 2001) (noting the recent creation of several new SSOs, including RosettaNet, a collection of information technology and semiconductor manufacturing companies, and the National Committee for Information Technology Standards, which promotes interoperability standards for information systems, storage media, and programming languages). 
effects, and increased rates of innovation. Each category provides benefits to both consumers and producers, and acts to increase the overall allocative efficiency within related product markets. This Part will examine each of these categories in turn, and will illustrate the important role that SSOs play in the modern economy.

\section{Interoperability.}

Uniform technical standards for a class of products ensure that consumers can mix and match the goods of rival firms without fear of product incompatibility. For example, a uniform technical specification for videotapes facilitates consumer choice by allowing consumers to choose between Maxell tapes and Sony tapes for their Sony camcorder. Accordingly, interoperability increases consumer welfare by promoting price competition between interoperable products. ${ }^{1}$ Furthermore, uniform technical standards reduce the information costs associated with acquiring a product in the first place, since consumers can rely on their knowledge of interoperable products when evaluating and comparing products. ${ }^{12}$

\section{Network effects.}

In many industries, interoperability does more than facilitate price competition. Uniform product standards can increase the value of products for all consumers, creating a demand-side economy of scale (in other words, a market where consumer demand for a product increases as the product becomes more widely used). ${ }^{13}$ These beneficial effects are referred to as "network effects," since they require a network of interrelated products to occur. For example, a single isolated fax machine is of little value if there are no other fax machines with which to communicate. However, the value of a fax machine grows rapidly as interoperable machines join the existing network. If

11 See, for example, Cowie and Lavelle, 30 AIPLA Q J at 99 (cited in note 6) ("The benefits that accrue from interoperability standards are well established. Interoperability increases consumer welfare by enhancing consumer choice and reducing the costs of goods.").

12 See Douglas D. Leeds, Raising the Standard: Antitrust Scrutiny of Standard-Setting Consortia in High Technology Industries, 7 Fordham Intel Prop, Media, \& Enter L J 641, 644 (1997) ("[S]tandardization permits easier consumer comparison between competing products because the burden of acquiring information on the merits of two competing standards is avoided. Thus, standardization reduces the cost of acquiring information."); David A. Balto, Standard Setting in a Network Economy, in Intellectual Property Antitrust 499, 509 (Practising Law Institute 2001) (Intellectual Property Course Handbook Series Number G-658) (arguing that standards "increase price competition, because standard technologies and products can be more readily compared and contrasted").

13 For a detailed discussion of network effects, including an in-depth look at economies of scale on the demand side, see Michael L. Katz and Carl Shapiro, Systems Competition and Network Effects, $8 \mathrm{~J}$ Econ Persp 93 (Spring 1994). 
fax machines were to operate on rival networks, or if specific brands of fax machines were to use incompatible standards, the value of individual fax machines would drop dramatically; consumers might be forced to purchase and maintain multiple fax machines, using their Xerox fax machine to communicate with others using the Xerox standard, and their Canon fax machine to communicate with others using the Canon standard. By ensuring that different products can work with each other, a single technical standard for product interoperability can eliminate the need for separate redundant products, raise the value of all interoperable products in the network, benefit producers by expanding consumer demand for their products, and benefit consumers by increasing the value of all products within a given network.

The benefits created by network effects can be direct or indirect. A direct benefit is the value added to the network when additional users join, directly benefiting all network participants. ${ }^{15}$ An indirect benefit is the increased demand for complementary products or postpurchase services that is created when a network's value increases." When suppliers respond to the increased value of the network by offering new complementary products or post-purchase services, existing and future network users receive the benefits of greater choice and increased competition for these products."

Because of their application in many information technology markets, network effects (and the technical standards for interoperability that create network effects) are an increasingly important element of the modern economy. ${ }^{18}$ Beyond fax machines, possible network industries include phone systems, railroads, credit cards, and computer software, hardware, and operating systems. In these industries, standard setting is crucial to creating and maintaining value for

14 This discussion of network effects draws heavily on the work of Douglas Lichtman and Randal C. Picker in Entry Policy in Local Telecommunications: Iowa Utilities and Verizon, 2003 $\mathrm{S} \mathrm{Ct} \operatorname{Rev}$ (forthcoming), online at http://www.law.uchicago.edu/faculty/lichtman/resources/ verizon300.pdf (visited Apr 25, 2003).

15 See Gates, 47 Emory L J at 594-95 (cited in note 5).

16 See id at 594 (noting that in network industries, "the addition of a new user spurs demand for complementary products or post-purchase service").

17 See id ("If more people buy Windows-based personal computers (PCs), more firms will make applications software for that type of PC. If more people buy video disk players, more stores will rent video disks. If more drivers choose Toyotas, more Toyota repair facilities will exist.").

18 See David J. Teece, Information Sharing, Innovation, and Antitrust, 62 Antitrust L J 465, 473-77 (1994) ("The advantages to society associated with the widespread adoption of common standards can be very large, as network externalities are often considerable."); David A. Balto, Standard Setting in the 21st Century Network Economy, 18 Computer \& Internet L 5, 5 (June 2001) ("[N]etwork economics accounts for an increasingly larger share of the economy. It is also the driving force behind many of the innovations and technological changes that occur."). 
consumers and producers, and to protecting the direct and indirect benefits of network effects.

\section{Innovation.}

Uniform technical specifications are a critical element of research and development efforts." Attempts to create new products carry a substantial degree of risk, since there is no guarantee that commercial research will ultimately yield viable products. In addition to uncertain consumer preferences and unforeseeable market intervention, a product may fail to yield positive returns because it has become technically obsolete by the time it is ready for market, or because intervening technical developments will have eliminated the target market for the product. Because uniform standards increase the likelihood that a given technology will be used throughout a product market, a firm can rely on a ready-made market for a new product so long as the product is interoperable with other products employing the existing industry standard. ${ }^{20}$ Accordingly, firms face a lower degree of risk when attempting to develop complementary products and postpurchase services in standardized markets. ${ }^{2 t}$

Uniform technical standards also encourage innovative improvements to existing products. By establishing a technical baseline for incremental product improvements, firms are not required to duplicate the costs of creating the initial product, and can instead rely on a certain level of functionality among the existing product and related products. ${ }^{2}$ Standards also reduce the costs of developing and commercializing improved products, since their compatibility assures easy integration into existing markets by incorporating the industry standard into their design. ${ }^{23}$ Standardization avoids the tremendous waste in-

19 See note 7 and accompanying text.

20 See Gates, 47 Emory L J at 599 (cited in note 5) (noting that a uniform industry standard "alleviates the risk of producing [new products] because the single standard ensures consumer acceptance").

21 See id at 612 ("Because compatibility standards ensure that products made by various competitors can work together, these standards may encourage innovation in the complementary goods market.").

22 See Leeds, 7 Fordham Intel Prop, Media, \& Enter L J at 644 (cited in note 12) (noting that a uniform industry standard "avoids inefficient duplication of investments in comparable, yet incompatible, innovation").

23 See id at 648:

[S]tandardization may improve competition by promoting innovation. Without a single accepted and open standard, firms that wish to improve on current technology would be forced to gain acceptance for an entire standard, rather than for a compatible product.... However, if a single accepted and open standard exists, consumers can adopt compatible technological improvements without surrendering network externalities.

In turn, firms will be encouraged to take advantage of the network's size by investing in innovative improvements to existing standardized products. 
herent in developing functionally similar but incompatible products, since firms are not forced to "reinvent the wheel" when developing products that conform to existing technical standards. By reducing the high fixed costs associated with research and development efforts, standardization also reduces the natural barriers to entry faced by new firms in markets characterized by high rates of innovation. In this way, uniform technical standards for product functionality encourage incumbents and entrants to compete through innovation, improving the baseline functionality of their products while preserving interoperability through adherence to the industry standard. ${ }^{24}$

Finally, industry standards are important sources of innovation because of the network effects they generate. Because network externalities create demand-side economies of scale, firms are encouraged to tap into these high-value, high-demand markets by developing new complementary products, creating new post-purchase services, or improving existing products that are used in the network. ${ }^{25}$ Without the high consumer demand that standardization and network economies create, many firms might not be willing to incur the high fixed costs associated with new product research and development, or assume the risks of those costly efforts. ${ }^{26}$ Given these powerful effects on innova-

24 See Lemley, 28 Conn L Rev at 1079 (cited in note 8) ("[S]tandard setting may also promote competition in the development of improvements to the standard, since each of the competitors may seek advantage over the others by improving the design in ways compatible with the basic interface specifications.").

25 See Balto, 18 Computer \& Internet $\mathrm{L}$ at 5 (cited in note 18) ("[N]etwork economics accounts for an increasingly larger share of the economy. It is also the driving force behind many of the innovations and technological changes that occur.").

26 Although standardization encourages innovation by reducing the risks of research and development, some critics argue that the costs of displacing or replacing entrenched standards may stifle or delay future innovation. These critics argue that because transitions from old standards to new standards reduce the value of products adhering to the old standard, the costs of switching from one network to another may create "lock-in" to a specific technology, since consumers will be unwilling to buy into new standards unless the improved functionality of the new standard justifies the cost of abandoning existing investments in the old standard. See Gates, 47 Emory L J at 595-96 (cited in note 5) (arguing that the QWERTY standard for keyboards prevails to this day because lock-in effects prevent the adoption of a new, more efficient standard); Leeds, 7 Fordham Intel Prop, Media, \& Enter L J at 650-51 (cited in note 12):

It is possible that, even though every consumer would prefer a product based on the new standard, the cost to the first switchers of abandoning the network, coupled with the uncertainty that other consumers would also switch and eventually build up the new network, may be so high that no consumers are willing to be the first switchers.

Because the debate on lock-in through standardization is ongoing and involved, this Comment will not address those particular concerns with the standard-setting process. However, it deserves mention that many scholars have questioned the validity of the lock-in argument. See generally S. J. Liebowitz and Stephen E. Margolis, The Fable of the Keys, 33 J L \& Econ 1 (1990) (criticizing the use of QWERTY as an example of path dependant lock-in given the scarce scientific evidence on more efficient designs). See also Carole E. Handler and Julian Brew, The Application of Antitrust Rules to Standards in the Information Industries-Anomaly or Necessity?, 14 No 11 Computer Law 1, 3 (Nov 1997) (using "the VHS VCR displacement of Betamax technology" to 
tion incentives, SSOs are critical components of technology markets and industries driven by innovation.

\section{B. Proprietary Standards and Patent Policies}

When firms collaborate to set product standards, they face an important choice about the type of standard they want to adopt. Technical standards come in two flavors: "open" standards, which are not controlled by any one party and can be adopted freely by all market participants; and "closed" or proprietary standards, which may be used only with the permission of the standard owner." Standards that incorporate technologies covered by patents are examples of "closed" standards, since they cannot be used without a license from the patent owner. SSOs, and the firms they represent, only face the threat of price-fixing liability when specifying the licensing terms for "closed" standards, since "open" standards are always freely available and require no license. While SSOs could avoid price-fixing problems altogether by limiting themselves to open standards, this alternative would limit the rate of technical progress in many industries. Closed standards typically offer greater technical benefits than open standards, since the high-risk, high-cost research programs required to develop cutting-edge technologies rely on patent protection to recoup the costs of research and development. ${ }^{28}$

Beyond the price-fixing problems that SSOs face when selecting closed standards, proprietary technologies also pose access problems not associated with non-patented technologies, because these closed

illustrate that lock-in effects are not insurmountable); Stan J. Liebowitz and Stephen E. Margolis, Path Dependence, in Boudewijn Bouckaert and Gerrit De Geest, eds, I Encyclopedia of Law and Economics: The History and Methodology of Law and Economics 981, 993 (Edward Elgar 2000) (noting that "[i]n spite of Beta's two-year head start, the market shifted very quickly to a format that offered an advantage to consumers," and concluding that "[w] hat this case actually demonstrates is not lock-in but rather the ability of markets to facilitate a switch from one path or standard to another"). Furthermore, any potential lock-in problems are directly addressed by the update requirements of some SSOs. See Gates, 47 Emory L J at 654-55 (cited in note 5) (noting that some SSOs have established policies requiring periodic upgrades of standardized technology and arguing that such policies should be mandatory).

27 See Kevin J. Arquit, Arman Y. Oruc, and Richard Wolfram, Antitrust, Intellectual Property, Standards and Interoperability, in Intellectual Property Antitrust 157, 182 (Practising Law Institute 1998) (PLI Patents, Copyrights, Trademarks, and Literary Property Course Handbook Series No G-524) (discussing the differences between open and closed standards). Perhaps the most popular form of an "open" standard is the TCP/IP protocol suite for switched-packet network traffic on the Internet. For a discussion of the Internet Engineering Task Force's standardization process, see S. Bradner, The Internet Standards Process $\$ 7.1$, online at http://www.ietf.org/ rfc/rfc2026.txt (visited Apr 25, 2003).

28 See Robert P. Taylor, Pilkington, Microsoft, and S.C. Johnson Signal a Policy Shift at $D O J, 9$ Antitrust 23, 25 (Fall 1994) (noting "the benefits of licensing proprietary technology, including efficiencies derived from combining technology with capital and other inputs and expanded availability to consumers of new technology and the products it creates"). 
standards cannot be used without a license from the patent owner. When an SSO adopts a proprietary technology as an industry standard, the owner of that technology obtains considerable market power, since all market participants adhering to the standard must obtain a license from the patent owner. This grant of market power can (and often does) result in monopoly pricing for patent licenses, thereby reducing license output and restricting access to the closed standard. ${ }^{29}$ These access problems threaten the benefits of standardization described above, since uniform technical standards are of little benefit to producers or consumers unless they are available to all competing manufacturers and uniformly adopted throughout the industry. ${ }^{30}$

In order to prevent the harms associated with monopoly pricing, many SSOs have implemented patent policies regarding new proprietary standards. If a company's patent covers an industry standard, SSOs typically require the company to disclose that patent to all SSO members before the technology is considered as a potential industry standard. If the company's patented technology is ultimately approved as a new standard, that company is subsequently required to waive all rights to the patent or offer SSO members licenses under "fair," "reasonable," "nondiscriminatory" terms. . $^{31}$ SSOs, however, never evaluate the substance of these offers before or after the patented technology

29 See Dennis W. Carlton and Robert H. Gertner, Intellectual Property, Antitrust and Strategic Behavior 6 (NBER Working Paper 8976), online at http://www.nber.org/papers/w8976 (visited Apr 25, 2003) (noting that when a patent owner with monopoly power decides to offer licenses, "downstream firms often face a monopolistically set input price for the licensed technology"); James J. Anton and Dennis A. Yao, Standard-Setting Consortia, Antitrust, and HighTechnology Industries, 64 Antitrust L J 247, 261 (1995):

In the case of a standard that effectively requires the use of a proprietary technology, the standard ... can imbue the technology with market power that it previously lacked. Thus, there is the potential for monopolization, or more minimally a raising of rivals' costs, through the conjunction of an adopted standard and a proprietary technology.

30 See Lemley, 28 Conn L Rev at $1059-60$ (cited in note 8):

The network externality effect ... suggests that network goods optimally should be priced as cheaply as possible, to allow widespread adoption of the standard. A proprietary standard owned by a single company which can set whatever price it wants does not seem the best way to achieve this goal.

(emphasis added). Note that the solution outlined in Part III of this Comment would eliminate the access problem identified by Lemley, since the collective bargaining power of the SSO would constrain the patent owner's ability to "set whatever price it wants."

31 See, for example, Townshend v Rockwell International Corp, 55 USPQ2d (BNA) 1011, 1018 (ND Cal 2000) (noting the patent owner's obligation to offer "reasonable" and "nondiscriminatory" licenses under an SSO patent policy); Institute of Electrical and Electronics Engineers' Standards Association Standards Board Operations Manual, cls 6.3.1-6.3.2 (2002), online at http://standards.ieee.org/guides/opman/sect6.html\# (visited Apr 25, 2003) (requiring that patent licenses "be made available to all [SSO members] either without compensation or under reasonable rates, terms, and conditions that are demonstrably free of any unfair discrimination"). 
is adopted as the industry standard. ${ }^{32}$ Patent owners need only promise to supply "fair," "reasonable," "nondiscriminatory" licenses to SSO members; beyond that requirement, SSO patent policies offer no guidance as to what specific license terms should look like, nor do they include penalty provisions for non-compliance. SSOs leave this language intentionally vague in order to avoid liability for price fixing. ${ }^{33}$ This policy requires SSO members to negotiate individually with a patent owner whose technology has recently attained considerable market power, and leaves no role for the SSO in determining the "fair," "reasonable," "nondiscriminatory" nature of subsequent patent license offers.

\section{The Threat to Standard Setting: Conflicts over "Fair," "Reasonable," "Nondiscriminatory" License Terms}

Because SSOs leave their patent policies intentionally vague to avoid antitrust liability, conflicts over the precise licensing obligations of the patent owner repeatedly arise. After a patent owner's proprietary technology is adopted as an industry standard by an SSO, individual SSO members must negotiate with the patent owner over the appropriate "fair," "reasonable," "nondiscriminatory" license terms." However, because the patent owner enjoys broad control over access to the new industry standard, individual SSO members often face unreasonably high prices for patent licenses. ${ }^{35}$

When SSO members reject a patent owner's license offer as unreasonable or discriminatory, the parties frequently resort to litiga-

32 For example, the patent policy of the Telecommunication Standardization Bureau, a wing of the International Telecommunication Union (ITU), provides that if a standardization proposal incorporates technology that is patented or is part of a pending patent application, the patent holder should either waive his rights or "be willing to negotiate licenses with other parties on a non-discriminatory basis on reasonable terms and conditions." International Telecommunications Union, ITU-T Patent Policy, online at http://www.itu.int/ITU-T/dbase/patent/patentpolicy.html (visited Apr 25, 2003). However, the policy goes on to state that "such negotiations are left to the parties concerned and are performed outside the ITU-T." Id. The ITU does not consider the substance of the licensing provisions in deciding whether or not to adopt a particular standard. Instead, the ITU assesses whether the patent holder is willing to negotiate such terms, and leaves the actual negotiation over price to the individual parties. If a patent holder claims to be willing to negotiate licenses "on reasonable terms and conditions," the ITU patent policy provides that the "detailed arrangements arising from patents (licensing, royalties, etc.)" must be negotiated by the individual parties. Id.

33 According to lawyers involved in the SSO process as FTC counsel or private representatives of high-tech companies, "SSOs have been reluctant to specify or become involved in setting royalty rates for patented technology for fear that they will be accused of price fixing or another violation of the antitrust laws" Cowie and Lavelle, 30 AIPLA Q J at 102 (cited in note 6). See also Gray, Internet Standard Setting Bodies at 534 (cited in note 10) (advising SSOs to "[a]void using the standards setting body as a means of price fixing, for example, by fixing licensing fees").

34 See note 31 and accompanying text.

35 See Carlton and Gertner, Intellectual Property at 6 (cited in note 29). 
tion. In such litigation, patent owners typically allege patent infringement, ${ }^{37}$ while SSO members typically allege patent misuse, attempted monopolization, and breach of implied contract. ${ }^{38}$ These disputes carry great risks, both for SSO members and for patent owners. SSO members risk liability for patent infringement, and perhaps willful infringement, which carries treble damages. ${ }^{39}$ Patent owners risk patent cancellation or unenforceability of their patents, ${ }^{\text {to }}$ compulsory royalty-free licensing, ${ }^{41}$ or antitrust liability, which may result in an award of treble damages.

Moreover, litigation over "fair," "reasonable," "nondiscriminatory" license terms is unusually long and protracted, imposing significant costs on patent owners and SSO members engaged in these disputes (as well as the public, which is forced to bear the lawsuits' administrative costs).

36 See, for example, Agere Systems Guardian Corp v Proxim, Inc, 190 F Supp 2d 726, 735 (D Del 2002) (dispute between an SSO member and a patent owner over "reasonable and nondiscriminatory" terms for patent licenses); Townshend, 55 USPQ2d at 1018 (dispute between an SSO member and the owner of a standardized technology over "reasonable terms and conditions" for a patent license); ESS Technology, Inc v PC-Tel, Inc, 1999 US Dist LEXIS 23227, *2-3 (ND Cal) (dispute between an SSO member and the owner of a standardized technology over "reasonable" and "non-discriminatory" patent license terms).

37 See Agere Systems, 190 F Supp 2d at 728 (addressing allegations of patent infringement by SSO member); Townshend, 55 USPQ2d at 1014 (same).

38 See Agere Systems, 190 F Supp 2d at 728 (describing SSO member's claim that patent owner's patent was unenforceable due to inequitable conduct); ESS Technology, 1999 US Dist LEXIS 23227 at *6-7 (dismissing SSO member's claim that patent owner attempted to monopolize the market for computer modems); id at *9-10 (allowing SSO member's claim for specific performance of patent owner's implied contract with the SSO "to negotiate licenses to [SSO members] on a non-discriminatory basis and on reasonable terms and conditions").

39 See 35 USC $\$ 284$ (2000) (allowing treble damages for willful patent infringement). The size of these damages can be astounding; damages for patent infringement are among the largest awards ever ordered by American courts. See David Hricik, Remedies of the Infringer: The Use by the Infringer of Implied and Common Law Federal Rights, State Law Claims, and Contract to Shift Liability for Infringement of Patents, Copyrights, and Trademarks, 28 Tex Tech L Rev 1027, 1033-34 (1997) (noting that damages for patent infringement "are at an all-time high," averaging over \$2 million per case, with the two largest awards for patent infringement in 1991 totaling $\$ 1.1$ billion).

40 See United States v American Bell Telephone Co, 128 US 315, 373 (1888) (holding that the United States can sue for the cancellation of a patent); Townshend, 55 USPQ2d at 1024 (evaluating and rejecting SSO member's claim that patent owner's patent was unenforceable due to patent misuse).

41 See United States v General Electric Co, 115 F Supp 835, 843-46 (D NJ 1953) (ordering royalty-free patent licensing "[i]n view of the fact that General Electric achieved its dominant position in the industry and maintained it in great measure by its extension of patent control"); In the Matter of Eli Lilly and Co, 95 FTC 538, 546-51 (1980) (entering consent decree requiring royalty-free licensing of certain patents for a period of five years).

42 See, for example, Cowie and Lavelle, 30 AIPLA Q J at 100 (cited in note 6) (noting that in a dispute over licensing practices, "the patent holder may risk a treble-damages action under the Sherman Act").

43 See Robert A. Skitol, The Shifting Sands of Antitrust Policy: Where It Has Been, Where It Is Now, Where It Will Be in Its Third Century, 9 Cornell J L \& Pub Pol 239, 266 (1999) (noting 
Given the potential liability and substantial cost accompanying litigation over "fair," "reasonable," "nondiscriminatory" license terms, vague SSO patent policies have greatly increased the cost and risk associated with selecting a proprietary standard. In turn, this increased risk discourages SSO participation, either by SSO members or patent owners. Indeed, many firms are for the first time questioning whether participation in SSOs is justified, given the potential liability exposure." Liability concerns are becoming more widespread, and if left unchecked, threaten the viability of the SSO process in many industries. ${ }^{45}$

By increasing the costs associated with SSO participation, conflicts over "fair," "reasonable," "nondiscriminatory" license terms jeopardize the beneficial effects of technical standardization. To preserve SSO activity and enjoy the benefits of standardization, these high-risk conflicts must be avoided. Although these conflicts could easily be prevented if SSOs specified licensing terms prior to the adoption of a proprietary standard, price-fixing liability stands in the way of an efficient resolution.

\section{ANTITRUST, PATENTS, AND PRICE FIXING: PRECEDENT AND PRINCIPLES}

Generally, antitrust law emphasizes maximizing allocative efficiency through lower prices and increased output. As noted in Part I, uniform technical standards promote those goals by increasing competition and reducing research costs. However, despite these procompetitive benefits of standard setting, this Part argues that current precedent threatens SSOs with liability for price fixing if their patent policies require anything more specific than "fair," "reasonable," "nondiscriminatory" license terms. Because price-fixing precedent does not presently reflect the procompetitive effects of standardization and SSO activity, and instead necessitates the vague language in

that "virtually all kinds of antitrust litigation-government and private alike-take too long and cost too much"); Amanda Kay Esquibel, The Rule of Avoidable Consequences in Antitrust Cases: A Law and Economics Approach, 26 Hofstra L Rev 891, 915 n 142 (1998) (lamenting "the protracted and expensive nature of antitrust litigation" and suggesting that "investing monies and efforts elsewhere may yield a greater return than the payment of those same funds to counsel and an array of experts"). See also Roger M. Milgrim, 3 Milgrim on Licensing $\$ 18.42$ at 18-69 (Matthew Bender 2002) ("[M]ost corporate counsel have concluded that patent litigation is the most expensive form of litigation, surpassing even so notoriously complex and expensive a form as antitrust litigation.").

44 See Cowie and Lavelle, 30 AIPLA Q J at 102 (cited in note 6) (noting that the risk associated with disputes over patent license terms is "threatening to chill legitimate standard-setting activity," and that many groups "are beginning to question whether participation in an SSO is justified").

45 See id (noting that litigation over vague SSO policies endangers the feasibility of standard-setting activity). 
SSO policies that causes high-risk litigation between SSO members and patent owners, this Part concludes that price-fixing rules should be reexamined in light of traditional and modern antitrust concerns.

\section{A. Goals of Antitrust Enforcement}

Over the past several decades, antitrust enforcement has undergone a small revolution, shifting its emphasis away from intent and towards economic effects. ${ }^{46}$ This economics-focused view of antitrust law, often referred to as the Chicago School, ${ }^{47}$ has exerted considerable influence on antitrust enforcement ${ }^{48}$ and has visibly influenced the Supreme Court's modern antitrust jurisprudence.

The Chicago School uses maximization of consumer welfare as the guiding principle for antitrust enforcement decisions, with reduced prices and increased output serving as rough measures for success. Those principles are still regarded as the main goal of antitrust en-

46 See, for example, John E. Kwoka, Jr. and Lawrence J. White, The Antitrust Revolution: Economics, Competition, and Policy 1 (Oxford 3d ed 1999):

[O]ver the past twenty years, there has been a revolution in U.S. antitrust policy. This revolution has involved the ascendence of economics in antitrust policymaking, with repercussions throughout the institutions and enforcement practices of antitrust. Economic analysis now plays a crucial role in determining what cases the Antitrust Division of the U.S. Department of Justice and the Federal Trade Commission actually pursue. . . . Courts have endorsed a central role for economics in rendering their own decisions.

47 The term "Chicago School" is used to refer to a body of antitrust views, first articulated by Aaron Director in the 1950s and expanded upon by Richard Posner and Robert Bork in the 1970s, emphasizing economic analysis of monopoly and advocating the use of economics as a tool for effective antitrust enforcement policy. See generally Richard A. Posner, The Chicago School of Antitrust Analysis, 127 U Pa L Rev 925 (1979) (detailing the origins and ideas of the Chicago School).

48 See A. Douglas Melamed and Ali M. Stoeppelwerth, The CSU Case: Facts, Formalism and the Intersection of Antitrust and Intellectual Property Law, 10 Geo Mason L Rev 407, 416-17 (2002) ("[S]ince the Chicago School began to influence antitrust policy in the late 1970's and 1980's, antitrust doctrine has crystallized around sound notions of economic analysis."); Dror Ben-Asher, What's The Connection? Vietnam, the Rule of Law, Human Rights and Antitrust, 21 Houston J Intl L 427, 441 n 63 (1999) ("In the United States, largely due to the influence of the Chicago School, modern antitrust adjudication is almost exclusively concerned with maximization of consumer welfare.").

49 The first Supreme Court decisions reflecting a Chicago School perspective were not decided until the late 1970s. See Broadcast Music, Inc v CBS, Inc, 441 US 1, 19-24 (1979) (holding blanket license agreement among rivals affecting price is not illegal per se if it substantially lowers transaction costs under the rule of reason); Continental T.V., Inc v GTE Sylvania Inc, 433 US $36,57-59$ (1977) (holding that vertical non-price restraints are not illegal per se given the important economic justifications for these restrictions); Brunswick Corp v Pueblo Bowl-O-Mat, Inc, 429 US 477, 488-89 (1977) (holding damages remedy unavailable to rival challenging merger under antitrust laws, since its alleged injury -increased competition-was not an injury that antitrust laws were intended to address). However, the Chicago School's influence appeared as early as 1975 in appellate decisions taking supply substitution into account in defining markets. See generally Jonathan B. Baker, The Problem with Baker Hughes and Syufy: On the Role of Entry in Merger Analysis, 65 Antitrust L J 353, 354-56 (1997) (discussing appeals court decisions employing a Chicago School analysis). 
forcement today. However, given the particular characteristics of the modern information economy, many antitrust scholars have begun to emphasize other important goals of antitrust enforcement, including the peculiar economics of network industries and the importance of innovation. As the following sections will demonstrate, both the traditional and modern views of antitrust enforcement support policies designed to protect SSOs and the procompetitive benefits they generate.

\section{Antitrust and consumer welfare.}

Traditionally, antitrust policies have been directed towards maximizing consumer welfare. In the antitrust context, consumer welfare refers to the social gain created by a perfectly competitive market organization and pricing scheme. ${ }^{50}$ This consumer welfare measure includes both consumer surplus (defined as the price difference between what a consumer pays for a product and what she is willing to pay) and producer surplus (defined as the price difference between what a producer sells its product for and the minimum price at which the producer would be willing to sell). ${ }^{51}$ Accordingly, consumer welfare is not concerned with a pricing system's distributional effects, but rather with the overall allocative efficiency in a market, making no distinctions between benefits to producers or consumers. ${ }^{52}$

When prices are set competitively, consumer welfare is maximized, creating the optimum allocative efficiency. ${ }^{53}$ However, when prices are set monopolistically, the resulting decline in consumer surplus exceeds the increase in producer surplus, creating deadweight loss and reducing allocative efficiency. ${ }^{\text {st }}$ Antitrust law is therefore concerned with reducing monopoly prices, thereby increasing output and returning the market to its efficient equilibrium. This traditional focus on consumer welfare has clear implications in the SSO context: If the owners of patented technologies accepted as industry standards are charging monopoly prices for patent licenses-and the evidence

50 See Herbert Hovenkamp, Federal Antitrust Policy: The Law of Competition and Its Practice $\$ 2.3 \mathrm{c}$ at 74-76 (West $2 \mathrm{~d}$ ed 1999) (defining "consumer welfare" as used in antitrust precedent and commentary as "maximizing allocative efficiency").

51 See id.

52 However, one of the central tenants of Chicago School antitrust analysis is that by increasing allocative efficiency, we will over time lower prices and increase output, directly benefiting consumers. See Robert H. Bork, The Antitrust Paradox: A Policy At War With Itself 90-91 (Basic 1978) ("The law's mission is to preserve, improve, and reinforce the powerful economic mechanisms that compel businesses to respond to consumers.").

53 See Hovenkamp, Federal Antitrust Policy $\$ 2.3 \mathrm{c}$ at 75 (cited in note 50) (discussing optimum levels of efficiency in a "Pareto potential" model).

54 See id.

55 See id. 
suggests that they are ${ }^{56}$-traditional antitrust enforcement principles would support policies designed to return those prices to their competitive levels.

\section{Modern antitrust concerns.}

The particular economic realities of the modern economy, including the importance of product interoperability, the increasing significance of innovation, and the prevalence of network industries, have already begun to shape the policies of modern antitrust enforcers. Many industries, especially high-technology industries, are driven by innovation and require continuous research and development to create new products and services. The critical importance of innovation has led scholars, ${ }^{\text {s8 }}$ as well as officials at the Department of Justice and the Federal Trade Commission, ${ }^{59}$ to advocate antitrust policies that encourage increased innovation. Antitrust enforcement agencies have responded to these concerns, incorporating for the first time a formal analysis of innovation competition and dynamic efficiency into standard merger analysis. ${ }^{60}$ Furthermore, antitrust enforcement has recognized the importance of network industries to the modern economy.

56 See note 29.

57 For example, the former Chairman of the Federal Trade Commission recently noted the importance of innovation in growth markets, and recognized that "market participants' incentives and opportunities to innovate are increasingly important in the intellectual propertyintensive new economy." Pitofsky, 16 Berkeley Tech L J at 540 (cited in note 7). See also Richard J. Gilbert and Steven C. Sunshine, Incorporating Dynamic Efficiency Concerns in Merger Analysis: The Use of Innovation Markets, 63 Antitrust L J 569, 569-70 (1995) (advocating a close examination of effects innovation as part of standard merger analysis). At the time of publication, Gilbert and Sunshine were the Deputy Assistant Attorney General for Economics and the Deputy Assistant Attorney General for Mergers, respectively, in the Antitrust Division, U.S. Department of Justice.

58 See Pitofsky, 16 Berkeley Tech L J at 539 (cited in note 7) (noting that "innovation competition can yield great consumer benefits" and arguing that "incentives to innovate must be protected in intellectual property markets"); Gates, 47 Emory L J at 585-90 (cited in note 5) (discussing the importance of innovation in the modern economy, and advocating that courts incorporate effects on innovation into any antitrust analysis of standard-setting activities).

59 See Anne K. Bingaman, Assistant Attorney General, Antitrust Division, U.S. Department of Justice, Competition and Innovation: Bedrock of the American Economy, Address before the University of Kansas Law School (Sept 19, 1996), online at http://www.usdoj.gov/atr/public/ speeches $/ 960919 \mathrm{ks.htm}$ (visited Apr 25, 2003) (noting that "innovation is critically important to the advancement of this nation's economic interests," and therefore advocating antitrust policies that "make sure that private restraints do not narrow the potential sources of innovation"); Christine A. Varney, Commissioner, Federal Trade Commission, Why Innovation Market Analysis Makes Sense (March 15, 1995) (FTC News Release), available on Westlaw at 1995 WL 112078 (recognizing that "antitrust enforcers have a role to play in ensuring that competition among innovators is not reduced or retarded").

60 See United States Department of Justice and Federal Trade Commission, Antitrust Guidelines for the Licensing of Intellectual Property $\$ 3.2 .3$ at 10-11 (1995) (requiring agencies to conduct an analysis of "innovation markets" when mergers or joint ventures would impact research and development efforts). It should be noted that antitrust law has long recognized the 
Since network effects directly benefit producers and consumers by increasing the value of each product in the network, and indirectly benefit network participants by encouraging innovation directed toward new and improved products and post-purchase services, ${ }^{61}$ the procompetitive effects of networks and standardization have become important considerations for modern antitrust policy. ${ }^{62}$ Accordingly, programs designed to encourage innovation and preserve beneficial network effects - for example, by preserving incentives to participate in SSOs and establish interoperable products-would enjoy the support of modern antitrust policy.

\section{B. Price Fixing and Patents}

As noted above, the traditional and modern goals of antitrust policy lend support to the notion that SSO activity should be encouraged and protected, given its numerous procompetitive effects. Accordingly, a system of SSO price bargaining that increased access to industry standards and preserved incentives to participate in SSOs would serve the purposes of antitrust policy. However, this Part demonstrates that price-fixing precedent stands as a barrier to the proposed bargaining system; any SSO attempting to negotiate over the price of patent licenses could quickly incur Sherman Act liability for price fixing.

While the goals and guiding principles of antitrust enforcement have undergone significant changes in the past 30 years, ${ }^{63}$ price-fixing precedent has not changed significantly over the past century. Concerted efforts to raise the price of a product above competitive levels have been illegal for over one hundred years. ${ }^{64}$ Ordinarily, the policy against price fixing is entirely consistent with the traditional and mod-

importance of temporary monopoly in creating new products or cost-saving processes, and has therefore been receptive to Schumpeter's ideas regarding dynamic efficiency through "creative destruction." See generally Joseph A. Schumpeter, Capitalism, Socialism and Democracy 83 (Harper 3d ed 1950). However, the increasing importance of innovation in modern markets has prompted the Department of Justice to emphasize the importance of innovation in the modern economy, and to stress that the ultimate goals of antitrust are not competition, but allocative and dynamic efficiency. See William J. Kolasky and Andrew R. Dick, The Merger Guidelines and the Integration of Efficiencies into Antitrust Review of Horizontal Mergers, Address at the 20th Anniversary of the 1982 Merger Guidelines, 26-33 (June 10, 2002), online at http://www.usdoj.gov/ atr/hmerger/11254.pdf (visited May 15, 2003) (noting that the revised 1997 Merger Guidelines heavily emphasize the procompetitive effects of innovation and the goal of attaining increased dynamic efficiency).

61 See notes 13-17 and accompanying text.

62 See Federal Trade Commission Staff, 1 Anticipating the 21st Century: Competition Policy in the New High-Tech, Global Marketplace ch 10 at 11-13 (1996) (noting that network industries "bear characteristics that should command an antitrust enforcer's special attention").

63 See notes $46-47$.

64 See United States v Trans-Missouri Freight Association, 166 US 290, 333, 340-42 (1897) (finding price-fixing agreements illegal regardless of the "reasonableness" of the fixed rates); United States $v$ Joint Traffic Association, 171 US 505, 574-77 (1898) (same). 
ern goals of antitrust enforcement, since cartelization of a market quickly leads to allocative inefficiency and deadweight loss. ${ }^{65}$ However, price-fixing liability extends beyond attempts to raise prices: It encompasses all arrangements attempting to stabilize or tamper with competitive pricing. ${ }^{\infty}$ The law prohibits all attempts to fix prices, regardless of effect. Prohibited attempts to fix prices may be horizontal or vertical in their orientation, may attempt to create higher or lower prices, and may implicate manufacturers, retailers, or purchasers. ${ }^{6}$ While minimum price-fixing arrangements are the most intuitive concern of antitrust enforcement, maximum price fixing is also an important antitrust concern, since monopsony - a market with only one buyer and many sellers, in which the buyer uses its unequal bargaining power to drive prices below competitive levels - is a significant source of allocative inefficiency and deadweight loss. ${ }^{68}$

65 See W. Kip Viscusi, John M. Vernon, and Joseph E. Harrington, Jr., Economics of Regulation and Antitrust 127 (MIT 3d ed 2000) ("A cartel, in contrast to a merger that integrates the productive activities of the firms, can lead only to [deadweight] losses. ... The 'inherent nature' of price fixing is to suppress competition, and there are no beneficial effects."); Hovenkamp, Federal Antitrust Policy at $\$ 4.1$ (cited in note 50) (discussing the harmful economic effects of price fixing).

66 See United States v Socony-Vacuum Oil Co, 310 US 150, 221-26 n 59 (1940) (prohibiting any agreement that "tampers" with market prices).

67 See, for example, Arizona v Maricopa County Medical Society, 457 US 332, 348 (1982) (holding horizontal agreements fixing maximum prices illegal per se); Kiefer-Stewart Co v Joseph E. Seagram \& Sons, 340 US 211,260 (1951) (holding agreements fixing maximum resale prices illegal per se); Mandeville Island Farms, Inc v American Crystal Sugar Co, 334 US 219, 223-24 (1948) (holding that buyer cartels aimed at fixing prices below competitive levels are illegal per se); Socony-Vacuum Oil, 310 US at 221 (finding horizontal arrangements to "tamper" with prices illegal per se); Dr. Miles Medical Co v John D. Park \& Sons Co, 220 US 373, 408-09 (1911) (finding a vertical price-fixing agreement illegal per se).

68 See Frank H. Easterbrook, Maximum Price Fixing, 48 U Chi L Rev 886, 886 (1981) (noting that monopsonistic maximum price fixing "drives a wedge between the competitive price and the market price, to the detriment of efficiency"). Although the solution advocated in Part III introduces consolidation of buyers and therefore raises monopsony concerns, the probability of anticompetitive harm is extremely low. True monopsony results in reduced output by decreasing the number of sellers in a market. See Hovenkamp, Federal Antitrust Policy at $\S 1.2 \mathrm{~b}$ (cited in note 50). However, "if a maximum price agreement serves only to ... overcome conditions that have elevated price above marginal cost, the objections to monopoly and monopsony do not apply." Easterbrook, $48 \mathrm{U}$ Chi L Rev at 886. As discussed in Part I.B, the current pricing system used by SSOs encourages monopoly pricing for patent licenses, since patent owners conduct individual negotiations with SSO members only after their technology attains market power. By reversing the bargaining order and allowing buyers to consolidate, the single-source price bargaining system advocated in Part III would help return prices to competitive levels by equalizing the relative bargaining power of SSO participants and patent owners. Indeed, the bilateral monopoly created by the proposed bargaining system would correct monopoly distortions in the patent license market in much the same manner that unionization corrects for monopsony distortions in labor markets. See, for example, George J. Stigler, The Theory of Price 207-08 (Macmillan 3d ed 1966) (noting that "when a monopolistic seller deals with a monopolistic buyer," both firms will rationally maximize their profits by returning price and output to their competitive levels). Accordingly, monopsony objections do not apply to the proposed bargaining system, because that system would correct existing distortions in market pricing procedures and increase, 
In the patent license context, price-fixing policy must take additional factors into consideration. Patent owners are granted a legal monopoly over their invention for the life of the patent, and have the statutory right to refuse to license their technology to others. ${ }^{69}$ Because patent owners are entitled to restrict license output and charge the monopoly price for their patented product or technology, ${ }^{70}$ the Supreme Court in United States v General Electric Co ${ }^{n 1}$ granted patent owners immunity from price-fixing liability for license terms dictating minimum resale prices, reasoning that a patent owner's right to set prices for its invention must not be undermined by antitrust law. ${ }^{2}$

However, more recent decisions have taken a harder line against all forms of patent price fixing, limiting price-fixing immunity under General Electric to instances of individual dealings with a single patent owner and a single patent licensee. ${ }^{73}$ Furthermore, the Department of Justice has stated that although General Electric is still good law, it will evaluate horizontal price restraints contained in patent licenses under the rule of reason, weighing efficiency prospects and procompetitive benefits against the potential anticompetitive harms, and will evaluate naked restraints in such licenses using a per se analysis.

Given these broad prohibitions against price fixing, SSOs have reason to be wary of antitrust liability. By fixing the terms, price, or output levels of patent licenses offered to SSO members, an SSO could be liable under several theories: horizontal price fixing ${ }^{75}$ (if viewed as the patent owner's competitor in the market for technological standards); vertical price fixing (if viewed as a consumer of pat-

rather than decrease, the patent owner's license output.

69 See 35 USC $\$ 271$ (d) (2000) (establishing a patent owner's right to refuse licenses for the patented technology, or to require cross-licensing in the absence of market power).

70 See id.

71272 US 476 (1926).

72 See id at 494. In the wake of General Electric, courts have extended immunity to patent owners for output restrictions in patent licenses as well. See Ethyl Corp v Hercules Powder Co, 232 F Supp 453, 460 (D Del 1963); United States v Parker-Rust-Proof Co, 61 F Supp 805, 812 (ED Mich 1945).

73 See, for example, United States v United States Gypsum Co, 333 US 364, 399-400 (1948) (holding that patent owners can be liable under antitrust law for licensing arrangements fixing prices industry wide, and arguing that General Electric "gives no support for a patentee, acting in concert with all members of an industry, to issue substantially identical licenses to all members of the industry under the terms of which the industry is completely regimented"); Newburgh Moire Co v Superior Moire Co, 237 F2d 283, 291-94 (3d Cir 1956) (limiting General Electric to an agreement between a single patentee and a single licensee).

74 See United States Department of Justice, Antitrust Guidelines for the Licensing of Intellectual Property $\$ 5.1$ at 24 (cited in note 60).

75 See Maricopa, 457 US at 332 (holding horizontal maximum price-fixing agreements illegal per se).

76 See Mandeville Island Farms, 334 US at 223-24 (holding that buyer cartels comprised of retailers and distributors are illegal per se). 
ented technologies); or a combination thereof ${ }^{n}$ (if viewed as a third party to the industry coordinating exchanges between patent owners and market participants). Therefore, under existing rules of antitrust enforcement, SSOs are faced with a Hobson's choice: implement patent policies with vague "fair," "reasonable," "nondiscriminatory" requirements that lead to high-risk litigation, or forego patented technologies altogether. Because the threat of antitrust enforcement imposes these unappealing choices on SSOs and necessitates the vague "fair," "reasonable," "nondiscriminatory" language in SSO policies, current antitrust policy should be reassessed to reflect the important welfare-enhancing functions performed by SSOs.

\section{Single-Source Patent Price Bargaining Should Be DECLARED PER SE LEGAL}

Although existing precedent would expose SSOs to antitrust liability for specifying the price terms of patent licenses, this Part proposes that the goals of antitrust law can be achieved by adopting a rule of per se legality for single-source patent price bargaining between SSOs and patent owners. Under this bargaining system, an SSO would be free to negotiate specific license terms with patent owners, including the pricing schemes for licenses to SSO members, prior to adopting a proprietary technology as an industry standard. As a result of this bargaining process, the price of patent licenses would be reduced, access to proprietary industry standards would improve, and firms with new access to the proprietary standard would enter the market and increase competition. Moreover, the proposed bargaining system would eliminate high-risk conflicts over "fair," "reasonable," "nondiscriminatory" license terms, thereby preserving incentives to participate in the SSO process and protecting the existing social benefits of product standardization.

\section{A. Per Se Legality Is an Established Element of Antitrust Law}

Antitrust law has long separated activities into categories of per se analysis as an efficiency tool, thereby reducing administrative costs and shifting burdens from plaintiffs to defendants when a behavior is clearly procompetitive or anticompetitive. ${ }^{78}$ Although per se rules are

77 See United States Gypsum Co, 333 US at 364 (holding attempts to fix the price of patent licenses for an "entire industry" illegal).

78 See United States $v$ Container Corp of America, 373 US 333, 341 (1969) (arguing that per se categories "are justified on the assumption that the gains from imposition of the rule will far outweigh the losses and that significant administrative advantages will result.... [T] competitive harm plus the administrative costs of determining in what particular situations the practice may be harmful must far outweigh the benefits that may result."); Viscusi, Vernon and Harrington, Economics of Regulation and Antitrust at 125-27 (cited in note 65) (discussing the 
more commonly used to classify practices as illegal, ${ }^{79}$ rules of per se legality are also established elements of antitrust law.

In United States $v$ Colgate \& $\mathrm{Co}^{\mathrm{s}}$, the Supreme Court unequivocally exempted manufacturers from antitrust liability for terminating retailers that failed to adhere to the manufacturer's suggested retail price, thus establishing the practice as per se legal. ${ }^{81}$ Although concerted attempts at vertical price maintenance were illegal per se, ${ }^{82}$ the Colgate Court carved out a category of behavior that was beyond the purview of antitrust enforcement, and exempted that category of behavior from liability. ${ }^{83}$ This analysis was entirely in line with the traditional rationale for per se categorization of behaviors, since the administrative costs of reviewing all unilateral attempts to maintain minimum resale prices far outweigh the potential for anticompetitive harm.

Since Colgate, courts have extended per se legality to other areas of antitrust enforcement, ${ }^{84}$ and academic commentators have suggested that the ranks of per se legality be expanded. ${ }^{85}$ Indeed, any category of behavior potentially within the purview of antitrust law but without any serious potential for anticompetitive harm is a potential candidate for categorization as per se legal, since evaluating specific instances of those behaviors would almost certainly impose administrative costs far in excess of the potential harm associated with the behavior. ${ }^{86}$ Antitrust law has long recognized that the categoriza-

rationale for and economic benefits of categorical analysis).

79 See, for example, Arizona v Maricopa County Medical Society, 457 US 332, 348 (1982) (holding horizontal price fixing illegal per se); Kiefer-Stewart Co v Joseph E. Seagram \& Sons, 340 US 211 (1951) (holding vertical price fixing illegal per se).

80250 US 300 (1919).

81 See id at 305-07.

82 See Dr. Miles Medical Co v John D. Park \& Sons Co, 220 US 373, 408-09 (1911).

83 See Colgate, 250 US at 307.

84 See Concord Boat Corp v Brunswick Corp, 207 F3d 1039, 1062 (8th Cir 2000) (holding that heavy price discounts, so long as prices remain above costs, are per se legal); Morgan $v$ Ponder, 892 F2d 1355, 1360 (8th Cir 1989) (holding that "prices above average total cost are legal per se").

85 See Peter Nealis, Note, Per Se Legality: A New Standard in Antitrust Adjudication under the Rule of Reason, 61 Ohio St L J 347, 380-82 (2000) (advocating the abolition of the rule of reason in favor of a more efficient "per se legality" standard in antitrust law); Richard A. Posner, The Next Step in the Antitrust Treatment of Restricted Distribution: Per Se Legality, $48 \mathrm{U}$ Chi L Rev 6, 8 (1981) (proposing that purely vertical restrictions on distribution, including price restrictions, be declared legal per se).

86 See Posner, 48 U Chi L Rev at 23 (cited in note 85):

The same considerations of judicial economy and legal certainty that justify the use of per se rules of illegality in some cases justify the use of rules of per se legality in others. Given the absence of either theoretical or empirical grounds for condemning [a practice] as anticompetitive, to declare [that practice] legal per se would serve both to lighten the burden on the courts and to lift a cloud of debilitating doubt from practices that are usually and perhaps always procompetitive. 
tion of behaviors as legal or illegal must change over time in light of new economic realities. ${ }^{\text {" }}$ Per se legality for SSO price bargaining would not only reduce administrative costs and provide SSO members with much-needed legal certainty, but would also create substantial economic benefits by reducing the price of patent licenses, increasing access to industry standards, fostering competition in standardized markets, and preserving incentives to participate vigorously in SSOs. As the remainder of Part III demonstrates, these substantial procompetitive effects justify recategorization of single-source patent price bargaining as per se legal.

\section{B. Single-Source Patent Price Bargaining Defined}

Under the proposed bargaining system, SSOs would be free to consider specific license terms as part of their negotiations with patent owners and could require patent owners to offer SSO members patent licenses with specific price, output, and length terms before adopting a proprietary technology as an industry standard. By including price as an element of the SSO selection process, SSOs would be free to balance the technological advantages of a proprietary standard against its owner's pricing requirements, making decisions based both on technical excellence as well as access to the standard. Although some might object to this bargaining system on the grounds that it would weigh technical gains against price and reduce the overall pace of technical progress, the criticism would be unwarranted. The price and access restrictions associated with proprietary standards are already important considerations in the SSO selection process. ${ }^{88}$ Allowing SSOs to engage in negotiations for specific price terms would only improve the accuracy of the current process, allowing SSOs to correctly gauge the cost of potential standards and make appropriate tradeoffs between technical functionality and commercial viability.

87 See, for example, State Oil Co $v$ Khan, 522 US 3, 18 (1997) (holding that there is "insufficient economic justification for per se invalidation of vertical maximum price-fixing agreements"); Broadcast Music, Inc v CBS, Inc, 441 US 1, 24-25 (1979) (holding that a fixed-price music licensing arrangement was not illegal per se, given the additional economic benefits created by the licensing arrangement); Continental TV, Inc v GTE Sylvania Inc, 433 US 36, 59 (1977) (holding that because of possible efficiencies, vertical non-price restraints are no longer illegal per se).

88 See Mark A. Lemley, Standardizing Government Standard-Setting Policy for Electronic Commerce, 14 Berkeley Tech L J 745, 756 (1999):

The right choice between open and closed standards is a complex one. Factors that go into determining social welfare include the technical quality of the standards, the possibility of improving those standards over time, the variety and price of products that embody the standards, and the size of the market that will result, as well as the speed of adoption and durability of the winning standard. 
Such a system of price bargaining would be allowed only over one or more patents originating from a single source, in order to prevent "capture" in an SSO setting." When patents are pooled into a collective entity, the interests of many competitors whose patents make up the pool may overlap. ${ }^{\text {.0 }}$ These overlapping interests may create a collusive desire to raise the price of patent licenses and that desire could be satisfied through the participation of multiple patent owners in the SSO process (either by co-opting the SSO selection process directly, or by gradually reducing the adversarial nature of the price bargaining process).

In contrast, when patents originate from a single source, the bargaining process between SSO members and the patent owner would be marked by a purely adversarial desire to reduce the costs of patent licenses. This adversarial relationship is crucial to effective bargaining. If, to the contrary, the interests of several SSO members align with those of the patent owner, or once several SSO members combine to represent a single pooled technology, the potential for cartelization and "capture" is too great to justify per se legality. ${ }^{91}$ Patent pools, joint ventures, and cross-licensed technologies should therefore fall outside

89 By "capture," I refer to the exercise of undue influence within the standard-setting organization, allowing individual members or factions to convert the SSO into a vehicle for personal gain. For example, if multiple SSO members combined their own patents into a patent pool, approved that pooled technology as the new industry standard, and then fixed industrywide licensing terms at unduly high prices, industry participants not included in the patent pool would be adversely affected, as would the consumers of that industry's products. Furthermore, a powerful faction of SSO participants with financial interests in a particular technology could adversely affect the bargaining process by distorting the ordinary selection process. For an example of SSO capture, see Allied Tube \& Conduit Co v Indian Head, 486 US 492, 501 (1988) (extending antitrust liability to the captors of a standard-setting organization, and encouraging SSOs to adopt "procedures that prevent the standard-setting process from being biased by members with economic interests in stifling product competition"). For a discussion of SSO capture, see David A. Balto, Antitrust and High-Tech Industries: The New Challenge, 43 Antitrust Bull 583, 600-03 (1998) (discussing the potential for anticompetitive harm through SSO capture); Mark A. Lemley and David McGowan, Legal Implications of Network Economic Effects, 86 Cal L Rev 479, 522 n 186 (1998) (noting the harmful effects of capture on innovation); Lemley, 28 Conn L Rev at $1081,1086-88$ (cited in note 8 ) (discussing several potential sources of SSO capture). For a detailed analysis of SSO capture through intellectual property rights, see Janice M. Mueller, Patent Misuse through the Capture of Industry Standards, 17 Berkeley Tech L J 623 (2002) (discussing capture through member non-disclosure of pending or existing patents on proposed industry standards).

90 For a detailed discussion of the many forms that patent collaboration can take, see Steven C. Carlson, Note, Patent Pools and the Antitrust Dilemma, 16 Yale J on Reg 359, 362-70 (1999) (discussing patent pools, joint ventures, cross-licensing arrangements, and other collaborative organizational schemes for blocking, complementary, and competing patents).

91 However, the exclusion of pooled or cross-licensed patents from the proposed bargaining system should not be read as an endorsement for per se illegality. Because the potential anticompetitive harms posed by these collaborative technologies will depend on the structure and procedural rules of specific SSOs, a thorough rule-of-reason analysis seems appropriate for multi-source price bargaining schemes, given the potential procompetitive results that bargaining could have on price, output, and access. 
the scope of the proposed bargaining system, thus preventing the anticompetitive harms associated with SSO "capture."

The solution outlined above is subject to two major criticisms: First, that the proposed bargaining process would create undue delays in the standard-setting process, and second, that a system of price bargaining would reduce incentives to innovate and develop improved proprietary technologies. While neither criticism is meritless, each objection misunderstands the current standard-setting process and the broader benefits of single-source patent price bargaining.

Adding a bargaining phase to existing standard-setting procedures would undeniably create a delay at the beginning of the SSO process. Negotiations over price take time, and if the product cannot be used until a price is set, negotiations over price will hinder the speedy employment of a standard. Critics may therefore argue that single-source patent price bargaining is an unworkable solution, because it would hamper SSO activities and delay the implementation of industry standards. However, this criticism ignores current delays in the standard-setting process. Because patent policies are left vague, individual SSO members must negotiate license terms with patent owners after a proprietary technology is adopted as an industry standard. During this subsequent period of negotiation, the adopted standard is far from useful, since SSO members can use the new standard only after completing negotiations over license terms. Because many negotiations fail to reach an agreement over "fair," "reasonable," "nondiscriminatory" terms and end in high-risk litigation, the SSO process currently experiences delays when implementing proprietary standards. ${ }^{93}$ The proposed solution would not exacerbate such delays, but would instead shift them to the beginning of the SSO process, thereby eliminating high-risk, time-consuming litigation after the adoption of the standard.

Other critics may decry the reduction of monopoly pricing for patent licenses, arguing that a reduction in the revenues received by

92 Although many technologies involve pooled or cross-licensed patents, a significant number of conflicts over "fair," "reasonable," "nondiscriminatory" license terms would be eliminated under the proposed single-source price bargaining system. See, for example, Townshend $v$ Rockwell International Corp, 55 USPQ2d 1011, 1026 (ND Cal 2000) (dismissing an SSO member's attempted monopolization and conspiracy to monopolize claims against an owner of 56K modem patents); ESS Technology, Inc v PC-Tel, Inc, 1999 Dist LEXIS 23227, at *12-14 (ND Cal) (dismissing manufacturer's Sherman Act and unfair competition claims against a single-source licensor of modem patents, but allowing patent misuse and other claims to proceed).

93 See Mueller, 17 Berkeley Tech L J at 623 (cited in note 89) (noting that when conflicts arise over license terms, "[a]bsent a mechanism to compel licensing, a hold-up problem ensues").

94 Furthermore, by conducting one consolidated round of negotiations before the adoption of the standard, as opposed to many individual negotiations afterwards, the proposed bargaining system could potentially reduce the time and transaction costs associated with licensing negotiations. 
patent owners would diminish incentives to innovate and develop patented technologies. ${ }^{95}$ It is certainly true that higher rates of innovation are created by such incentives, and that reducing a patent owner's revenues could lead to fewer investments in new technology. However, this criticism ignores the procompetitive effects of standard setting, effects that single-source patent price bargaining would encourage. ${ }^{96}$ By improving access to patented standards and increasing the size of network externalities, single-source patent price bargaining would reduce the risk of research and development projects, thereby encouraging future innovation and offsetting any long-term losses created by a reduction in monopoly pricing." In light of the important benefits of single-source patent price bargaining, neither the delay caused by price negotiations nor the potential reduction in long-term investments in research and development presents an insurmountable hurdle to the proposed solution.

\section{Single-Source Patent Price Bargaining Would Encourage Vigorous Participation in SSOs}

By obviating the need for vague licensing requirements in SSO patent policies, per se legality for single-source patent price bargaining would eliminate conflicts over "fair," "reasonable," "nondiscriminatory" license terms. SSOs would instead specify the terms of patent licenses, including price, prior to adopting a proprietary technology as an industry standard. In turn, the potential liability created by conflicts over "fair," "reasonable," "nondiscriminatory" license terms

95 From the outset, it should be noted that this criticism lacks substance unless the current level of investment in research and development is the optimal level of investment, a presumption that lacks empirical support. See Carlton and Gertner, Intellectual Property, Antitrust and Strategic Behavior at 29 (cited in note 29) (noting that "the determination of the optimal level of R\&D remains elusive," and therefore that "it does not follow that simply because creation of a closed system may reduce $R \& D$ that the new level of $R \& D$ is less than optimal").

96 See notes 19-26 and accompanying text.

97 This trade-off between high rents and low risk may have independent efficiency benefits, since it may reduce rent-seeking behaviors by patent owners. Rent-seeking will occur if patent owners earn revenues far in excess of their fixed research and development costs, leading to over-investment in research and development and causing detriment to other capital investment programs. See, for example, Viscusi, Vernon, and Harrington, Economics of Regulation and Antitrust at 90-95 (cited in note 65) (discussing the relative advantages of competitive innovation through rivalry in research and development markets, as compared to Schumpeterian innovation through monopoly rents, and illustrating that monopoly rents are not always required to achieve high rates of innovation); Kenneth Dam, Economic Underpinnings of Patent Law, $23 \mathrm{~J}$ Legal Stud 247, 251-52 n 14 (1994) (noting that rent-seeking leads not only to inefficient duplication of research and development expenditures, but also "cause[s] R \& D expenditures to be made at a faster than optimal rate"). By encouraging innovation through reduced risk, rather than high rents, rent-seeking behaviors may be reduced or eliminated, improving the overall efficiency of capital investment.

98 See notes $34-42$ and accompanying text. 
would no longer be borne by SSO participants, and current concerns over SSO participation ${ }^{*}$ would be moot. Accordingly, a single-source patent price bargaining system allowing SSO members to bargain collectively with patent owners terms would not only result in lower prices for patent licenses, but would also preserve incentives for vigorous SSO participation. By protecting the companies that form SSOs (and the patent owners that offer their technologies as industry standards) from the specter of price-fixing liability, per se legality for single-source patent price bargaining would protect the numerous benefits that standardization currently creates.

D. Single-Source Patent Price Bargaining Would Achieve the Goals of Antitrust Enforcement

If SSOs were allowed to bargain with patent owners over the price and terms of patent licenses as part of negotiations with a single patent owner, the resulting terms for patent licenses would increase consumer welfare, swell the number of firms using the new proprietary standard, and encourage innovative research into new and improved products and services. ${ }^{100}$ Accordingly, this system of bargaining would create the effects that modern antitrust policy seeks to generate and protect, ${ }^{102}$ thereby achieving the goals of antitrust enforcement through market mechanisms.

Under the current system, the price of patent licenses is determined after a proprietary technology has been adopted as an industry standard. However, at that point in the process, the SSO has already conferred incredible market power (in network industries, the entire product market) on a patent owner. Given this market power, patent owners have every incentive to offer licenses at monopoly prices, since those licenses are necessary inputs for all market participants adhering to the industry standard. Essentially, the current system requires uneven bargaining, pitting individual SSO members against a patent owner with complete control over an SSO member's ability to participate in the product market.

However, under the proposed system, SSO members would be allowed to bargain collectively with patent owners over the price and terms of licenses, thereby eliminating the inequality of actors in the bargaining process. ${ }^{102}$ SSOs could obtain lower prices for patent li-

99 See note 44 and accompanying text.

100 For a discussion of standardization's effects on innovation, see notes 19-26 and accompanying text.

101 See Part II.A for a summary of antitrust enforcement's concerns and goals.

102 The considerable bargaining power of SSOs is indisputable. At times, SSOs have convinced patent owners to waive all rights to or abandon their intellectual property rights in order to become the industry standard. See Kelly Flaherty, Standard Operating Procedure, The Re- 
censes, thereby forcing patent owners to commit to competitive prices in exchange for high market share. By locking the price of patent licenses in at a competitive level, single-patent price bargaining would increase the patent owner's license output and eliminate deadweight loss in the market for patent licenses. By reducing the price of patent licenses and increasing license volume, barriers to entry would also be reduced, consequently increasing the number of firms competing in the product market (since more firms would have access to the industry standard). In turn, this increased use of the industry standard would enhance and enlarge network effects, spurring demand-side economies of scale and encouraging future innovation.

Standard setting is an unusual process, in that market participants willingly select technologies as necessary inputs to production when they select proprietary technologies as industry standards. Effectively, SSO members collaboratively choose a technology and provide it with monopoly status, accepting the threat of monopoly pricing in exchange for the benefits created by standardization. In this unique situation, exempting SSOs from antitrust liability for price fixing would allow the victims of monopoly pricing to arrange that monopoly's prices from the ex ante perspective, thereby reducing or eliminating monopoly pricing while maintaining the benefits of industry standards. Accordingly, a system of single-source patent price bargaining would achieve the goals of antitrust enforcement through market mechanisms, thus eliminating the high administrative costs and error costs associated with litigation over the specific licensing obligations imposed on patent owners by SSO patent policies. ${ }^{103}$

\section{CONCLUSION}

Adopting a standard of per se legality for single-source patent price bargaining between patent owners and SSOs would not only achieve efficient pricing for patented standards, but would also encourage vigorous participation in SSOs since the bargaining process would eliminate the risks of litigation over "fair," "reasonable," and "nondiscriminatory" terms. This system would also eliminate the high administrative and error costs associated with litigation over license terms, suggesting that per se legality for single-source patent price

corder 1 (Dec 17, 1997) ("In order to hold on to the standard, [San Mateo based RSA Data Security] was forced to write a formal letter to the [Internet Engineering Task Force, an SSO,] agreeing to make public its proprietary ' $\mathrm{RC2}$ ' algorithm. The company also relinquished its trademark rights to S/MIME and agreed not to dominate the working group in charge of developing the standard."). See also Carlson, 16 Yale J on Reg at 394-95 (cited in note 90) (describing the SSO pressure that caused RSA to relinquish its patents in order to have its technology adopted as the standard for email encryption).

103 See notes $40-43$ and accompanying text. 
bargaining is a more efficient tool for achieving the goals of antitrust law than private or public litigation over "fair," "reasonable," "nondiscriminatory" license terms. 


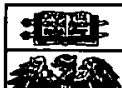

( $1, \cdots$ 